DOI: https://doi.org/10.24144/2409-6857.2018.1(51).223-229

УДК 331

Данилевич Н.С., Поплавська О.М., Олішевська А.В.

\title{
ОЦНЮВАННЯ ПЕРСОНАЛУ: ПРАКТИКА ВИКОРИСТАННЯ СУЧАСНИХ МЕТОДІВ, МОЖЛИВОСТІ ПОШИРЕННЯ В УКРАЇНІ
}

\begin{abstract}
У статті досліджено особливості прочесу очінювання персоналу в зарубіжних компаніях та Украӥни, визначено перспективи запровадження досвіду очінювання персоналу провідних компаній на вітчизняних підприємствах, окреслено можливі ризики. За результатами авторського дослідження виявлені недоліки оцінювання персоналу в Украӥні; доведено, щуо прочедури оцінювання персоналу найчастіше застосовуються при підборі персоналу та оцінюванні результатів праці.
\end{abstract}

Ключові слова: очінювання персоналу, підбір персоналу, ефективність очінювання персоналу, оцінювання результатів праці персоналу.

Постановка проблеми. Серед усіх функцій управління персоналом є одна, яка має прямий або опосередкований вплив на виконання інших - оцінювання. Вона, як функція управління персоналом, $\epsilon$ базою даних для прийняття значного кола управлінських рішень, пов'язаних 3 плануванням та підбором персоналу, його розвитком та мотивацією, управлінням процесами руху персоналу та регламентації трудової діяльності.

Оцінювання персоналу необхідно розглядати як важливий бізнес процес, який дозволяе виявити сильні і слабкі сторони колективу компанії, а також окреслити шляхи вдосконалення індивідуальних трудових здібностей працівника, дослідити ефективність системи мотивації персоналу. Основною метою оцінювання персоналу є покращення управління діяльністю організації. Відтак оцінювання персоналу дозволяє: планувати кар'єру та сприяє просуванню працівників по службі; визначати рівень компетентності спеціалістів; здійснювати перестановку кадрів 3 урахуванням потенціалу працівників; будувати психологічний портрет працівників організації; проводити ефективний підбір потрібних спеціалістів; досліджувати

(C) Данилевич Наталія Станіславівна, к.т.н., доцент кафедри управління персоналом та економіки праці, ВН3 «Київський національний економічний університет ім. Вадима Гетьмана», м. Київ, тел.: 0667289750, email: iljusha@ukr.net

Поплавська Оксана Миколаївна, к.е.н., доцент кафедри управління персоналом та економіки праці, ВН3 «Київський національний економічний університет ім. Вадима Гетьмана», м. Київ, тел.: 0500164085, email: oksanadom@ukr.net

Олішевська Анна Владиславівна, студентка кафедри управління персоналом та економіки праці, ВН3 «Київський національний економічний університет ім. Вадима Гетьмана», м. Київ, тел.: 0631408124, email: siniy462@gmail.com специфіку міжособистісних відносин і психологічний клімат у колективі; визначати міру задоволення і зацікавленості працівників в організації; знаходити засоби для закріплення в організації потрібних спеціалістів; розробляти ефективну систему мотивації трудової діяльності; раціонально використовувати методи роботи з персоналом.

На жаль більшість підприємств України оцінювання персоналу здійснюють лише на етапі підбору або оцінювання результатів праці працівників. Через це часто втрачаються важелі впливу організації на іiі людський капітал, не формується позитивний бренд роботодавця.

Аналіз останніх досліджень і публікацій. Про актуальність обраної теми свідчать численні дослідження зарубіжних науковців. Зокрема, Пулакос та О. Лірі стверджували, що система оцінки результативності неефективні, оскільки вони зосереджують увагу на адміністративних процесах (тобто на документах), а не на тренуванні менеджерів та розвитку співробітників щодо того, як брати участь у ефективній поведінці управління діяльністю (наприклад, повідомляючи чіткі цілі та очікування). Армстронг та Барон писали, що оцінювання продуктивності спрямовує та підтримує працівників, щоб вони працювали максимально ефективно відповідно до потреб організації. Ваніяла і Кімутай робили акцент на тому, що оцінка ефективності роботи працівників може бути використана для покращення поточного результату, надання зворотного зв'язку, підвищення мотивації, визначення потреб у навчанні, визначення потенціалу, дозволяють інформованим особам дізнатися, що від них очікується, зосередитись на розвитку кар'єри, збільшенні заробітної плати та вирішенні трудових проблем [1].

Серед зарубіжних авторів, які зробили значний внесок у розроблення цієї проблеми, також необхідно відзначити П. Друкера, 
М. Х. Мескона, Г. Мінцберга. Серед українських вчених проблемі оцінювання персоналу присвятили свої роботи В.М. Данюк, А.М. Колот, Є.В. Маслов, М.I. Мурашко, В.М. Петюх, В.А. Савченко, С.О. Цимбалюк та інші.

Формулювання цілей статті. Метою статті $\epsilon$ обгрунтування можливостей використання методів оцінювання персоналу зарубіжних компаній в Україні й аналіз практики оцінювання національними організаціями.

Опис основного матеріалу дослідження. Досліджуючи ефективність оцінювання персоналу українських компаній, ми звернули увагу на те, що чим більшою і стабільною $є$ компанія, тим грунтовніше працівники HRпідрозділів готують програми оцінювання. Разом 3 тим, акценти в оцінювані персоналу здебільшого розставлені на питаннях визначення результатів праці, рівня досягнення цілей та підборі персоналу. Наприклад, компанія ДТЕК здійснює щорічну оцінку персоналу шляхом обчислення ключових показників ефективності (КПЕ), тобто головною метою оцінювання $\epsilon$ визначення результативності [9].

Необхідно зазначити, українські підприємства оцінювання частіше застосовують для підбору персоналу. Оцінювання персоналу є елементом процедури підбору персоналу. На етапі добору кандидат знайомиться 3 компанією. У процесі професійного підбору визначають відповідність рівня освіти та досвіду роботи кандидата кваліфікаційним вимогам, а також рівень розвитку професійно важливих компетенцій, необхідних для ефективного виконання обов'язків на відповідній посаді. Процедура оцінювання кандидатів на вакантну посаду має свої специфічні особливості, проте основні правила, вимоги, принципи є спільними для будь-якого виду оцінювання.

Для визначення слабких та сильних сторін оцінювання на етапі підбору кандидатів на українських підприємствах нами було опитано 100 респондентів різного віку (до 25 років - 57\%, 25-30 років - 19\%, старше 30 років - 24\%), статі (жіноча $-76 \%$, чоловіча $-24 \%$ )) та рівня освіти (неповна вища - $31 \%$, бакалавр - $17 \%$, магістр $42 \%$, кандидат економічних наук - $4 \%$, спеціаліст - 3\%, середньо-спеціальна - 3\%), які задіяні у понад 20-ти різних сферах діяльності. $37 \%$ учасників опитування відзначило проведення первинної співбесіди як найважливіший етап добору персоналу (рис.1).

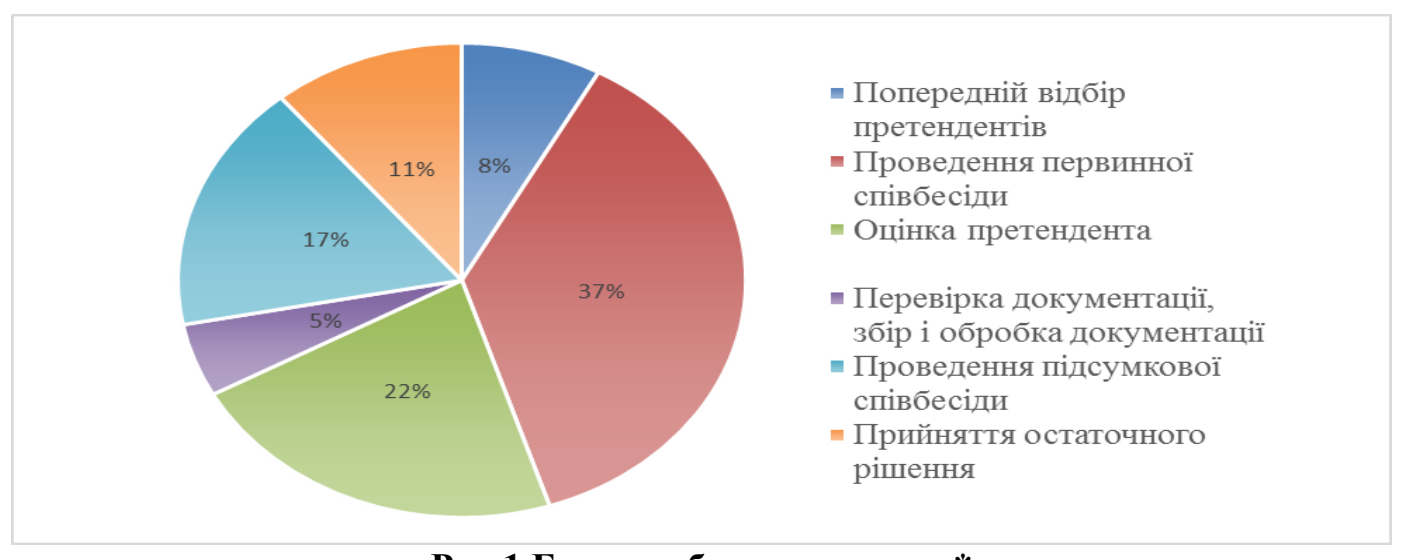

*Розроблено авторами

Рис.1 Етапи добору персоналу*

97\% наших респондентів хоча б раз у житті проходили співбесіду при влаштуванні на роботу. Вони вказали, що серед найпопулярніших дій сучасних фахівців 3 менеджменту персоналу $\epsilon$ ведення ділової розмови, вирішення кейсів та тестування під час співбесіди. Ми виявили, що $27 \%$ опитуваних нами осіб повністю задоволені роботою відділу кадрів на підприємстві, де вони працюють. 63\% оцінюють його роботу як задовільну, інші $10 \%$ незадовільно.

Також було визначено, що $35 \%$ опитуваних вважають працівників кадрових відділів достатньо залежними від зовнішніх факторів, які не мають прямого відношення до роботи 3 оцінкою нових претендентів. Враховуючи, що в нашому опитуванні брали участь співробітники освітніх та інших державних структур, медицини, промисловості та ін., ми маємо згадати та наголосити на неупередженості роботи фахівця служби-HR, яка потребує особливої уваги. Майже 1/3 наших респондентів вважають, що на їх підприємствах працюють працівники, які були дібрані неякісно. Учасники опитування наголошують на тому, що проходження співбесіди щодо визначення професійних компетенцій при відборі кандидатів на посади має бути більш грунтовним, разом 3 
цим необхідно звертати увагу й на психологічний і емоційний розвиток кандидата.

Таким чином, наше дослідження дозволяє зробити висновок про те, що методи, які застосовуються при підборі персоналу українськими компаніями, не достатньо ефективні.

Практика як українських, так і закордонних підприємств свідчить, що функції 3 проведення оцінювання персоналу розподіляються між лінійними керівниками та кадровими службами (департаментами управління персоналом). Вирішальна роль в оцінюванні персоналу належить безпосередньо начальнику, який добре знає своїх підлеглих, несе повну відповідальність за результати їх діяльності, застосування заходів заохочень та покарань, за їх навчання та розвиток. Метою такого оцінювання є:

$\checkmark$ прийняття рішення про просування працівників, їх переміщення на інші посади в інші структурні підрозділи;

$\checkmark$ інформування співробітників про те, як їх оцінює керівництво;

$\checkmark$ оцінка внеску кожного співробітника до колективного результату, оцінка результатів роботи структурних підрозділів щодо досягнення цілей компанії;

$\checkmark$ прийняття рішень щодо організації оплати праці;

$\checkmark$ діагностика рішень щодо навчання та розвитку персоналу.

Погоджуючись 3 думками респондентів нашого опитування, ми відзначаємо, що оцінювання керівником часто є суб'єктивним, необгрунтованим. Вважаємо, що у цьому випадку корисним буде досвід компанії «Хонда» в штаті Огайо (США). Оцінювання працівника чи кандидата керівником має бути доповненим іншими методами, зокрема, написання твору про співвідношення майбутньої роботи 3 життєвою метою кандидата та пї реалізацією [6].

Важливо відмітити, що закордонні компанії значну увагу при оцінювання кандидатів на вакантні посади застосовують психологічні методи - тести, що складаються 3 цифрових таблиць, геометричних фігур, лабіринтів тощо [4, 8, 11]. Психологічне тестування здебільшого грунтується на повторенні фраз або уривків 3 тексту, копіюванні малюнків тощо (наприклад, тести Біне, Сімоно, Отіс, Декудро). Тільки після проходження всіх таких перевірок вирішується питання про долю даного претендента.

Опрацювавши інформацію про використання методів оцінювання різними компаніями (табл.1) ми дійшли висновку, що вибір методу має бути у прямій залежності від стадії життєвого циклу організаціі. Це дасть можливість зробити систему оцінювання гнучкою та ефективною, відповідною завданням та стратегічним цілям компаніі.

На нашу думку, впровадження системи оцінювання може стати основою для підготовки «вирощування» талантів та майбутніх лідерів.

Зміст, переваги, недоліки та особливості застосування методів оцінювання персоналу*

\begin{tabular}{|c|c|c|c|}
\hline Метод оцінки & Зміст методу оцінки & Переваги та недоліки & $\begin{array}{l}\text { Рекомендації } \\
\text { використання }\end{array}$ \\
\hline Рейтинговий метод & 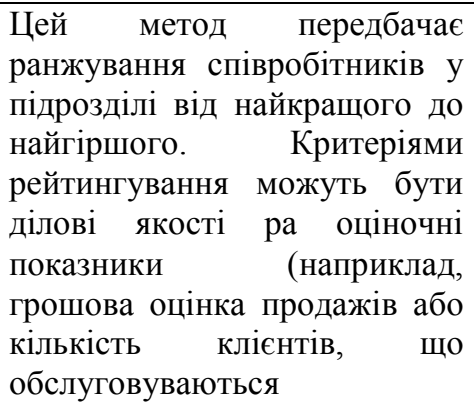 & $\begin{array}{lr}\text { Дозволяє } & \text { побачити } \\
\text { «критичні } & \text { точки» в } \\
\text { результатах, } & \text { визначити } \\
\text { еталон посади, проте } є \\
\text { занадто узагальненим, тому } \\
\text { не враховує індивідуальних } \\
\text { особливостей працівника } \\
\text { (тобто компанія не може } \\
\text { оцінити потенціал з метою } \\
\text { розвитку таланту). }\end{array}$ & \begin{tabular}{lrr} 
Для & \multicolumn{2}{r}{ оцінювання } \\
результативності & праці, \\
побудови & еталону \\
$\begin{array}{l}\text { посади на } \\
\text { «народження» }\end{array}$ & етапі \\
$\begin{array}{l}\text { організації } \\
\text { стабільного }\end{array}$ & та & \\
функціонування & &
\end{tabular} \\
\hline Метод есе & 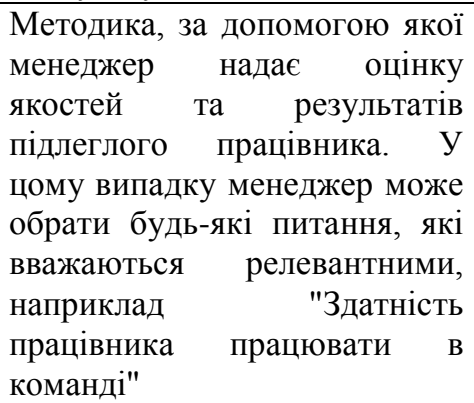 & \begin{tabular}{ll} 
Дозволяє & визначити \\
професійні & компетенції \\
(вирішення & практичних \\
кейсів за & \multicolumn{2}{c}{ напрямом } \\
діяльності), & проте \\
суб'єктивним. &
\end{tabular} & $\begin{array}{l}\text { Для визначення } \\
\text { професійної } \\
\text { спрямованості, сфери } \\
\text { (зони) відповідальності; } \\
\text { як допоміжний метод на } \\
\text { етапі «народження» } \\
\text { організації або спаду на } \\
\text { ринку }\end{array}$ \\
\hline
\end{tabular}




\begin{tabular}{|c|c|c|c|}
\hline & & & Продовження табл. 1 \\
\hline Метод оцінки & Зміст методу оцінки & Переваги та недоліки & $\begin{array}{l}\text { Рекомендації } \\
\text { використання }\end{array}$ \\
\hline $\begin{array}{l}\text { Графічні шкали } \\
\text { рейтингу }\end{array}$ & 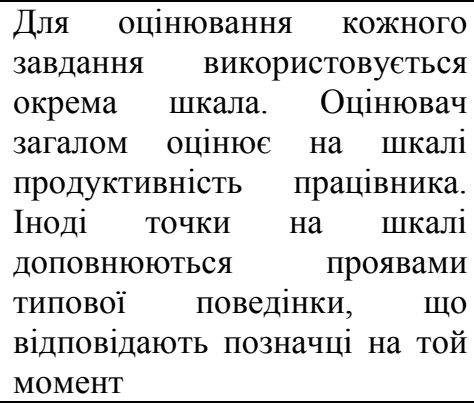 & $\begin{array}{lr}\text { Дозволяє } & \text { оцінити } \\
\text { досягнення } & \text { кожного } \\
\text { працівника, } & \text { побачити } \\
\text { «вузькі місця» } & \text { й обрати } \\
\text { шлях ї } & \text { усунення, } \\
\begin{array}{l}\text { підготувати } \\
\text { навчання }\end{array} & \text { програму } \\
\end{array}$ & $\begin{array}{l}\text { Для оцінювання } \\
\text { компетенцій, } \\
\text { результативності праці } \\
\text { на етапі розвитку } \\
\text { компанії }\end{array}$ \\
\hline Критична & \begin{tabular}{lrr} 
Передбачає & \multicolumn{2}{r}{ безпосереднє } \\
спостереження та фіксацію \\
прикладів хорошої або \\
неприйнятної поведінки на \\
роботі. Для цього оцінювач \\
веде щоденник із фіксацією \\
різних ситуацій, а потім \\
подає узагальнену оцінку \\
«усереднену» \\
поведінки)
\end{tabular} & $\begin{array}{l}\text { Дозволяє оцінити потенціал } \\
\text { працівника, вчасно } \\
\text { реагувати на зміни, проте } \\
\text { затратний, довготривалий } \\
\text { процес, вимагає обережного } \\
\text { проведення }\end{array}$ & $\begin{array}{l}\text { Для корекції планів } \\
\text { розвитку, виявлення } \\
\text { «вузьких місць» на етапі } \\
\text { стабільного } \\
\text { функціонування }\end{array}$ \\
\hline Примус & $\begin{array}{l}\text { Метод передбачає, } \\
\text { твердження, яибір } \\
\text { найкращим } \quad \text { чином описує } \\
\text { поведінку працівника } \\
\text { рядом параметрів. }\end{array}$ & $\begin{array}{lr}\text { Дозволяє } & \text { виявити } \\
\text { причинно-наслідкові зв'язки } \\
\text { між компетенціями та } \\
\text { результатами, } \\
\text { затратний процес, } \\
\text { від палежить } \\
\text { параметрів }\end{array}$ & 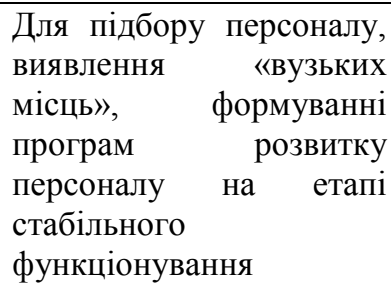 \\
\hline Метод $360^{\circ}$ & $\begin{array}{l}\text { Метод вимагає збір думок та } \\
\text { відгуків від керівників, колег, } \\
\text { споживачів та інших. }\end{array}$ & $\begin{array}{lr}\text { Дозволяє } & \text { здійснити } \\
\text { комплексне } & \text { оцінювання } \\
\text { досягнень працівника }\end{array}$ & $\begin{array}{lr}\text { Для } & \text { оцінювання } \\
\text { результативності праці } \\
\text { на будь-якому етапі } \\
\text { розвитку організації } \\
\end{array}$ \\
\hline $\begin{array}{l}\text { Assessment centers } \\
\text { (Оціночний центр) }\end{array}$ & 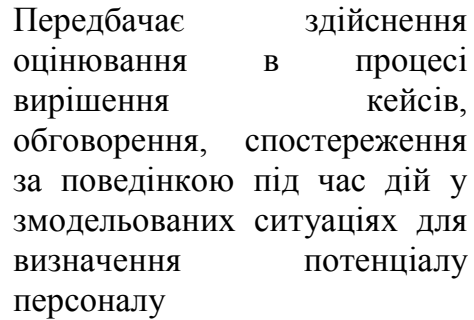 & 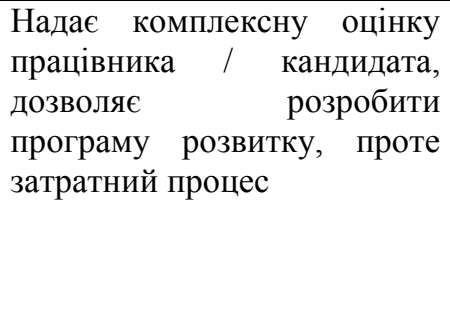 & 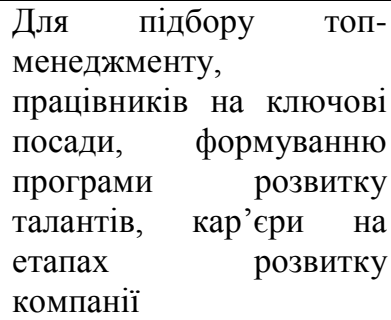 \\
\hline
\end{tabular}

* Розроблено авторами за джерелом [2, 3]

Адже фактична й оціночна інформація, що збирається на багатьох фірмах за найширшою програмою, являє собою реальну базу кадрового планування, розрахунку потреб у допоміжному персоналі, прогнозування програм корпоративного навчання, організації конкурсного заміщення вакантних посад $\mathrm{i}$, безумовно, оплати праці співробітників. У різних організаціях система оцінювання підпорядковується стратегічним цілям і завданням, тому залежно від кадрової політики вона дозволяє вирішити ті чи інші проблеми.

Так, дослідження ряду фірм США виявило критерії оцінки, що $є$ найбільш актуальними: 1) для оцінювання результативності праці: якість роботи (93\%), обсяги виконаних робіт (90\%), знання змісту роботи (85\%), кількість відпрацьованих годин $(79 \%) ; 2$ ) для оцінювання особистісних якостей: ініціативність (87\%), комунікативність $(87 \%)$, надійність $(86 \%)$, необхідність у контролі за виконуваною роботою (67\%) [5]. Тобто, як ми з'ясували в США значна увага приділяється ефективності оцінювання результатів діяльності персоналу (більше 90\% компаній застосовують ту чи іншу систему оцінювання результатів трудової діяльності).

Не менш поширеним методом оцінювання персоналу в США є атестація: за результатами атестації у 80,2\% компаніях було підвищено ефективність роботи. Систематична атестація дозволяє визначати і виправляти погані звички в

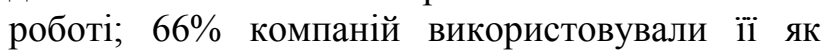


основу для просування по службі і переведень; на понад 63\% фірм вона дає докладні відомості про послужний список співробітників i досягнення для визначення розміру збільшення заробітної плати; більше, ніж на 61\% компаній атестація поліпшує моральний стан; майже 53\% компаній використовують ऑiі для визначення кандидатів на посади керівників i створення групи потенційних керівників [10].

Вважаємо за доцільне поширювати практику атестації за технологіями компаній США, що полягає у проведенні бесід зі співробітниками після атестації. У США дев'ять фірм 3 десяти, що застосовують систему атестації, повідомляють співробітникам результати головним чином в індивідуальних бесідах керівника 3 підлеглими. Саме це дозволяє організувати «зворотний зв'язок» 3 працівником, досягти максимальної прозорості процедури й розуміння цілей компанії працівниками.

Разом 3 тим, будь-який процес оцінювання не буде ефективним, якщо він не стане постійним процесом. Тому важливо здійснювати оцінювання щорічно. Існує також практика щорічної атестації. Наприклад, за відповідями студентів (авторське дослідження) у компанії «Макдональдс» керівники і спеціалісти в обов'язковому порядку повинні проходити атестацію при зміні посади, а також через шість місяців 3 часу найму, переміщення на іншу посаду; неформальне оцінювання нових працівників проводиться через три місяці, для переведених 3 однієї посади на іншу - через тридцять днів, а формальна - через півроку роботи. Такий жорсткий контроль, оцінювання сильних і слабких сторін діяльності працівника дозволяє компанії вчасно надати відповідну допомогу працівникові, швидко виправити недоліки. На нашу думку проведення частих формальних процедур оцінювання в період адаптації може сприяти прищеплюванню працівнику стандартів трудової діяльності організації, проте є ряд ризиків, пов'язаних 3 психологічною готовність працівника бути «цілодобово під наглядом». Тому таку частоту оцінювання не бажано запроваджувати для посад інноваційних та креативних сфер економічної діяльності .

Важливим питанням організації оцінювання $є$ підбір складу комісії, яка може дати об'єктивну ділову оцінку кандидата. 3 цією метою до оцінювання працівника рекомендуємо залучати, відповідно до методу $360^{\circ}$, колег, підлеглих і його самого. Сучасним трендом вважається здійснення самооцінювання, яке дозволяє визначити те, на скільки добре працівник знає свої сильні та слабкі сторони, котрі потім обговорюються. Тому результати самооцінки у подальшому можуть бути обговорені відповідною комісією 3 оцінювання (частіше керівником та колегами). У цьому разі працівник повинен чітко вказати перелік всіх виконаних ним робіт за оцінюваний період. Така інформація слугує для виявлення узгодженості посадових обов'язків 3 реальними обсягами та змістом виконуваних робіт, а також дозволяє оцінити якість виконання завдань. За такої технології важливе місце в оцінюванні має співбесіда між керівником і підлеглим. Працівник, одержавши на руки екземпляр оціночної форми, має змогу обговорити сильні і слабкі сторони своєї діяльності.

3 позицій ефективного управління персоналом вважаємо, метою обговорення має стати не тільки донесення бачення результативності діяльності, але й пошук мотивів та стимулів до продуктивної праці оцінюваного, спрямування його на розвиток власних навичок $\mathrm{i}$ знань. За результатами обговорення необхідно розробити конкретну програму дій щодо напрямків усунення недоліків в роботі і розвитку ділових якостей працівника, узгодження цілей працівника та компанії.

При розробці «програми дій» організації США та Японії, як правило, залучають самих працівників 3 метою підвищення відповідальності виконавців і покращення порозуміння між керівниками та підлеглими [5]. В деяких організаціях від працівників вимагають розробки програми своїх дій протягом місяця від дня обговорення результатів оцінювання. В інших випадках програми дії, що розробляються за результатами оцінок, включають не тільки перелік конкретних заходів, але й терміни їх виконання, Значна увага приділяється методичній стороні процедури оцінювання, особливо проведення співбесіди $[10,11]$. Вміння проводити обговорення підсумків оцінювання 3 підлеглими $\epsilon$ головним фактором, від якого залежить ефективність програми оцінювання трудової діяльності, тому більшість корпорацій проводить спеціальне навчання керівників всіх рівнів 3 проблем оцінювання діяльності підлеглих.

Оцінювання персоналу деяких українських та закордонних промислових підприємств характеризується декількома особливостями, пов'язаними 3 філософією виробництва, яка грунтується на пріоритетності цілей розвитку талантів, прояву i закріплення здібностей кожного [10]. У зв'язку 3 цим оцінювання персоналу розуміється як комплексна програма повної оцінки результатів праці, здібностей, характеру, здатностей до певного виду діяльності 
працівника. Справедливе оцінювання за такого підходу слугує основою для вирішення питань управління кар'єрою персоналу, що в свою чергу має важливе значення для мотивації працівників. Другою особливістю японської моделі оцінювання персоналу є досить щільний зв'язок результатів праці 3 оплатою і преміюванням. Наприклад, виплата премій обумовлюється оцінкою здібностей і результатом праці: інколи до $30-40 \%$ розміру заробітної плати становлять премії, доплаті і надбавки, які узгоджуються 3 результатами праці [10]. Третьою особливістю оцінювання кадрів на японських підприємствах $\epsilon$ iii регулярність, обов'язковість для всіх, що створює сприятливий психологічний клімат у колективі.

Висновки та перспективи подальших досліджень. В сучасних умовах для України вкрай актуальним $є$ досвід зарубіжних компаній щодо оцінювання результатів праці, яке можна здійснювати прямими методами (визначення продуктивності, результативності праці) та опосередкованими (оцінювання якостей, які впливають на досягнення результатів). Зазвичай стабільні транснаціональні компанії прагнуть поєднати обома названими групами методів. Українським компаніям, запроваджуючи ті чи інші методи оцінювання персоналу, важливо обрати найбільш ефективні (ті, які будуть відповідати цілям компанії, етапу життєвого циклу організації, характеру робіт, тощо). Варто також оцінити ступінь готовності компанії (у т.ч. персоналу) до таких новацій, проаналізувати наслідки, розробити програму оцінювання 3 прозорою системою моніторингу показників оцінки. Проте оцінювання має стати важливим управлінським процесом усіх українських компаній, адже найгіршим видом оцінювання працівників $\epsilon$ його відсутність. Фахівці 3 управління персоналом зазначають, що краще користуватися недостатньо відпрацьованими методиками для оцінювання працівників, аніж зовсім не приділяти увагу цьому напряму роботи. Підсумовуючи, хочемо відзначити, що проблема об'єктивності та якості оцінювання персоналу потребує подальшого дослідження, особливо в частині вибору методів оцінювання результативності та ефективності діяльності працівників, зайнятих в інноваційних сферах економіки.

\section{ПЕРЕЛІК ВИКОРИСТАНИХ ДЖЕРЕЛ}

1. Benedict Boadi. Performance appraisal and employee development in the civil service in the greater accra metropolis [Електронний pecypc]. https://erl.ucc.edu.gh/jspui/bitstream/123456789/3053/1/BENEDICT\%20BOADI.pdf

2. Plan, conduct and evaluate a staff performance assessment [Електронний ресурс]. - Режим доступу: http://www.asean.org/storage/images/2013/economic/matm/Toolboxes\%20for\%20Six\%20Tourism\%20Labour\%20Divi sions/Common $\% 20$ Competencies $\% 20$ (as $\% 20$ of $\% 20$ February $\% 202013$ )/Plan $\% 20$ conduct $\% 20$ and $\% 20$ evacuate $\% 20 \mathrm{a} \% 2$ 0staff\%20performance\%20assessment/TM_Plan_conduct_\&_evaluate_staff_pa_310812.pdf

3. Бондаревська К.В., Сорокотяга Т.Л. Оцінка персоналу: сучасні методи та інструменти ії проведення. [Електронний $\quad$ ресурс]. https://www.google.com.ua/url?sa=t\&rct=j\&q=\&esrc=s\&source=web\&cd=1\&ved=0ahUKEwj14aan1NTZAhVD66QK HVz0DF4QFggnMAA\&url=http\%3A\%2F\%2Firbis-nbuv.gov.ua\%2Fcgi-

bin\%2Firbis_nbuv\%2Fcgiirbis_64.exe\%3FC21COM\%3D2\%26I21DBN\%3DUJRN\%26P21DBN\%3DUJRN\%26IMA GE_FILE_DOWNLOAD\%3D1\%26Image_file_name\%3DPDF\%2Fpiprp_2013_2_8.pdf\&usg=AOvVaw1Z8BEcrtYrn QQzbwkcel_N

4. Григор'єва О. В., Галайда Т. О., Іскрук А. В. Формування ефективної системи оцінювання персоналу на підприємстві. // Ефективна економіка. - №11. [Електронний ресурс]. - Режим доступу: http://www.economy.nayka.com.ua/?op=1\&z=3542

5. Зарубежный опыт оценки персонала [Електронний ресурс]. - Режим доступу: http://azbukahr.com.ua/index.php?option=com_content\&task=view\&id=30

6. Иванов Р. Особенности оценки персонала в новой экономической ситуации / Иванов Р. // Менеджмент и менеджер. - 2009. - № 11-12. - С. 52-56.

7. Мороз М.М. Зарубіжний досвід управління персоналом. Наук. вісник НЛТУ України / М.М. Мороз// Львів: НЛТУ України, 2010. - 344 с.

8. Нижник В.М., Змерзла Т.І. Проблеми та перспективи комплексності оцінки персоналу підприємства.// Вісник Хмельницького національного університету - №5. - Т.1 - 2013. [Електронний ресурс]. - Режим доступу: http://elar.khnu.km.ua/jspui/bitstream/123456789/1188/1/NIZHNIK.pdf

9. Система оценки персонала в ДТЭК [Електронний ресурс]. - Режим доступу: https://hrliga.com/index.php?module=profession\&op=view\&id=1395

10. Управление персоналом: учебник : [пер.с укр.] / [В.М. Данюк, А.М. Колот, Г.С.Суков и др.]; под общ. и науч. ред. к.е.н., проф., В.М. Данюка. - К.: КНЭУ; Краматорск: НКМЗ, 2013. - 693с.

11. Цимбалюк С.О. Технології управління персоналом: навч. посіб. // С.О. Цимбалюк. - К.КНЕУ, 2009. 399c. 


\section{REFERENCES}

1. Benedict Boadi. Performance appraisal and employee development in the civil service in the greater accra metropolis (2016). Retrieved from: https://erl.ucc.edu.gh/jspui/bitstream/123456789/3053/1/BENEDICT\%20BOADI.pdf [in English]

2. Plan, conduct and evaluate a staff performance assessment (2013). Retrieved from: http://www.asean.org/storage/images/2013/economic/matm/Toolboxes\%20for\%20Six\%20Tourism\%20Labour\%20Divi sions/Common\%20Competencies\%20(as\%20of\%20February\%202013)/Plan\%20conduct\%20and\%20evacuate\%20a\%2 0staff\%20performance\%20assessment/TM_Plan_conduct_\&_evaluate_staff_pa_310812.pdf [in English]

3. Bondarevs`ka K.V., Sorokotyaga T.L. (2013) Ocinka personalu: suchasni metody` ta instrumenty yiyi provedennya. Retrieved from: https://www.google.com.ua/url?sa=t\&rct=j\&q=\&esrc=s\&source=web\&cd=1\&ved=0ahUKEwj14aan1NTZAhVD66QK HVz0DF4QFggnMAA\&url=http\%3A\%2F\%2Firbis-nbuv.gov.ua\%2Fcgi-

bin\%2Firbis_nbuv\%2Fcgiirbis_64.exe\%3FC21COM\%3D2\%26I21DBN\%3DUJRN\%26P21DBN\%3DUJRN\%26IMA GE_FILE_DOWNLOAD\%3D1\%26Image_file_name\%3DPDF\%2Fpiprp_2013_2_8.pdf\&usg=AOvVaw1Z8BEcrtYrn QQzbwkcel_N [in Ukrainian]

4. Gry`gor'yeva O. V., Galajda T. O., Iskruk A. V. (2014). Formuvannya efekty`vnoyi sy`stemy` ocinyuvannya personalu na pidpry'yemstvi. [Formation of an effective system of staff assessment at the enterprise] Efekty 'vna ekonomika - Eeffective econonomic, 11. Retrieved from: http://www.economy.nayka.com.ua/?op=1\&z=3542 [in Ukrainian]

5. Zarubezhnyiy opyit otsenki personala. [Foreign experience of personnel assessment] (2017). http://azbukahr.com.ua Retrieved from: http://azbukahr.com.ua/index.php?option=com_content\&task=view\&id=30 [in Russian].

6. Ivanov R. (2009). Osobennosti otsenki personala v novoy ekonomicheskoy situatsii [Features of personnel assessment in the new economic situation] Menedzhment $i$ menedzher - Management and Manager, 11-12, 52-56 [in Russian]

7. Moroz M.M. (2010). Zarubizhny`j dosvid upravlinnya personalom [Foreign experience in personnel management] Nauk. visny`k NLT Ukrayiny - Science fiction NLT writer of Ukraine , 344 [in Ukrainian]

8. Ny`zhny`k V.M., Zmerzla T.I. (2013). Problemy` ta perspekty`vy' kompleksnosti ocinky` personalu pidpry`yemstva. [Problems and perspectives of complexity of estimation of personnel of the enterprise] Visny` $k$ Xmel 'ny'cz'kogo nacional'nogo universy`tetu - Bulletin of the Khmelnytsky National University, 5. (vol.1) Retrieved from: http://elar.khnu.km.ua/jspui/bitstream/123456789/1188/1/NIZHNIK.pdf [in Ukrainian]

9. Sy`stema ocenky` personala v DTЭK. [The personnel evaluation system at DTEK] (2012). https://hrliga.com Retrieved from: https://hrliga.com/index.php?module=profession\&op=view\&id=1395 [in Russian].

10. Danyuk V.M., Kolot A.M., Sukov G.S. et al. (2013) Upravlenie personalom [Human resource management] Kiev: KNEU, Kramatorsk: NKMZ, 693 [in Russian].

11. Cy`mbalyuk S.O. (2009). Texnologiyi upravlinnya personalom [Human Resources Management Technologies] K: KNEU,. - 399s. [in Ukrainian]

Одержано 05.03.2018 p. 